\title{
休日の活動一交通の実態分析と休日調查へのインプリケーション An Analysis of Weekend Activity-Travel and Implications for Surveys on Weekend Activity*
}

\author{
佐々木 邦明**, 林 篤史***, 西井 和夫** \\ By Kuniaki SASAKI **, Atsushi HAYASHI ${ }^{* * *}$, Kazuo NISHII **
}

1.はじめに

\section{(1) 研究の背景}

これまでの交通計画では平日を中心に通勤・通学など の交通の量的充足を目的として行われてきた. しかし， 自動車の普及と地方部一の高速道路の延長や, 郊外型シ ヨッピングセンターの増加, 労働時間の減少といった 様々な社会的な環境の変化から, 休日の自由目的の自動 車交通が増加し, 都市の郊外部や，観光地などでの休日 の淥帯などが問題となってきている ${ }^{12)}$. そのため, これ からの交通計画では，このような特定の課題に対応可能 な, フレキシブルな休日の交通計画が必要となって来る ことが考えられる.しかし, 休日交通についての研究は, これまで主にいわゆる観光地と呼ばれる地域での交通を 主体とした分析であり ${ }^{344)}$, それ以外も, 買物目的や駐車 場選択など特定の課題に絞った交通行動の分析などに限 られ ${ }^{5) 6)}$ ，休日交通全体を把握する研究はあまり行われて いなかった. その理由としては, 休日交通がバラエティ に富み, 特性が大きく異なるため, 分析対象を絞り特性 が似かよった交通だけを対象とすることで分析を容易に するためと考えられる. 休日の総合的・課題対応型交通 計画を考えたときには, 休日交通全体の特性とそれを構 成する部分としての特性という関係性の中で捉えること が必要である.

\section{（2）「休日」の定義と行動特性の捉え方}

交通計画は一般に地域的・時間的な広がりを持ったも のであるため，交通計画上で休日を定義する場合には， 特定の個人にとっての休日ではなく, 集計的な意味で交 通の特性に基づいて「休日」を定義することが望ましい と考えられる ${ }^{1}$. そもそも個人にとっての休日とは, ど のような定義であるのか? 広辞苑によると休日とは「業 務・授業などを休む日」となっている. これより社会的 な意味において，1 週間の各曜日を平日と休日とに分類 できるとすると，休日とは，業務・授業などが休みとな

*Keywords : 休日交通, アクデイ゙゙デダ仍リ一, PT調查

**正員 工博, 山梨大学大学院医学工学総合研究部社会: $/ 74$ 工学領域（广400-8511 甲府市武田 4-3-11）

***学生員 山梨大学大学院医学工学総合教育部自然機能開発専攻 Tel\&Fax : 055-220-8671 E-mail: sasaki@yamanashi.ac.jp
る個人の割合の高い日が休日となるであろう．厚生労働 省の調査によると 7 完全週休 2 日の普及率は平成 15 年で ほぼ 90\%に達しており, その多くは土・日休日である. また小・中学校でも土曜・日曜が休日とっていることか ら土曜・日曜が休日に該当すると予想される. このこと から本研究では, 週末（土・日）を休日と定義すること とする.

これまでの交通特性の把握は観光旅行や自動車の更新 行動などの希少性の高い行動を除くと, 一般に 1 日を単 位として行われることが多く, 休日も同様に一日を単位 として主に日曜に調査されてきた ${ }^{8)}$. しかし先に述べた ように休日は土・日の連続した 2 日間となり, 筆者らの 先の研究 ${ }^{91}$ は土・日の生活時間配分は 24 時間を単位とす るのではなく, 48 時間を単位として分析をした方が有効 なモデルが作れることを示していた. また, 杉恵・芦沢

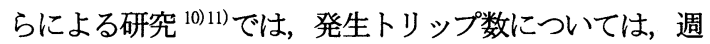
末においても, 曜日間の違いが認められ, 複数日間調査 の有効性が確認されている. そこで本研究では週末の各 種指標を通じて, 休日の望ましい分析単位を検証する.

\section{（3）休日の特性とアクティビティ分析}

休日特性をアクティビティ分析の視点からみると,「休 日」は場所・時間ともに固定的な活動を行う比率の低い 日であるといえる. 固定的な活動が少ないことは活動の 時間や場所の選択の自由度の増加を意味し, 手段や場所 の選択も個人の嗜好に応じてさまざまに変化することと なる. これは同時に交通の目的地選択や手段選択, 出発 時刻選択などのばらつきの増加を意味する. このように 休日の交通行動は, 自由度の高、生活行動に関係して変 化するため, 本研究ではアクティビティダイアリー（以 下AD) 調査のデータを用いて活動との関係性を明らかに することが望ましいと考えられる.しかし $\mathrm{AD}$ 調查に基づ くデータは一般に回答の対象となる項目が通常のトリッ プ調査と比較して多くなるため, 回答者の負担が大きく, 回答拒否・無回答によるサンプルバイアスや，回答精度 の低下 ${ }^{11}$ が生じやすくもなる，そこで休日を対象とし た調査の有效性を明確にするため, 土・日と連続でとら れた $\mathrm{AD}$ 調查データに基づいて, 休日調査として連続調查 が必要なのか，それとも特定の条件下では被験者の負担 の少ない 1 日の調査でよいのかを明らかにし, 休日の $\mathrm{AD}$ 
調査を行う場合に，調査の目的に応じた休日の調査日の 設定・分析に対してその指針となり得る知見を得ること を目的とする.

\section{2. 休日の生活行動とトリップの概要}

\section{（1）用いたデータの概要}

本研究で用いるデー夕は，1章で述べたように土・日 と連続で取られており，一定数以上のサンプルがある $\mathrm{AD}$ 調査データを必要とする. そこで, 分析対象としたデー 夕は, 第 4 回京阪神都市圈PT 調查の付帯調査として実施 された $\mathrm{AD}$ 調査である. 日曜日のみの交通実態については 本体のPT調査においてもなされたが,この $\mathrm{AD}$ 調査では, 休日交通への関心の高まりに対応し，平日，土曜日およ び日曜日の 3 日間の調査がなされた。

調査票は，世帯票と個人票で構成されているが，世帯 票は, 世帯構成員全員の個人属性（性別, 年齢, 職業, 勤務先・通学先, 勤務形態等) を尋祇ている. 一方, 個 人票は, 交通行動と生活行動の時間軸に沿った把握のた め, 平日, 土・日曜日のそれぞれについて, 活動開始・ 終了時刻, 活動種別, 移動手段, 移動先を記入させてい る. また, 個人票の調查票レイアウトは, 第 4 回京阪神 都市圈 $\mathrm{PT}$ 調查プリサーベイ時に実施された $\mathrm{AD}$ 調査で採 用されたアフターコードタイプである.

サンプル数は, 市区町村単位で一定の分析ができるこ とを目的として, サンプリング誤差が 10\%以下になるよ うに，各市区町村で 200 サンプルを確保することを目標 に設定された。調查対象地域は, 多様な生活パターンが 見込まれる都心部と, 周辺の居住系の市区町村とし, 大 津市, 彦根市, 京都市, 大阪市 (中央区と住吉区), 神戸 市 (中央区, 西区), そして奈良市であった.

また, 調査対象者の抽出は, 本体のPT 調査と一体的に 抽出が行なわれ (抽出間隔を $\mathrm{AD}$ 調査に必要な世帯数だけ 上乗せして設定), 無作為抽出によって $\mathrm{PT}$ 調査と $\mathrm{AD}$ 調査 の調查対象世帯が分離されている. なお, 調査票の配布・ 回収方法は, 調査対象者一の説明を考慮し, 訪問配布・ 訪問回収により行われ, 合計 1801 人分のデータが回収さ れた。

\section{（2）休日生活行動の実態}

京阪神 $\mathrm{PT}$ 付帯 $\mathrm{AD}$ 調査に基づく休日の生活行動の実態 を，基礎的な指標を示すことで概略を示す．まず，トリ ップ特性について簡単にまとめたものを表-1に示す.こ の結果からは, トリップにおいて平日と土・日曜では特 にグロスのトリップ数と, トリップ平均継続時間におい て差が見られる. また土曜と日曜の間では，グロスの平 均トリップ数において土曜日が日曜を上回り, ネットの 平均トリップ数では土曜日が最も高い. グロス・ネット
の平均トリップ数は, 分散分析を行った結果, 統計的に 有意な差があった.このように同じ週末である土曜と日 曜では，土曜日に外出する人が多いが，トリップチェー ン数は似た傾向にあることがわかる.

表 - 1 平日・土曜・日曜のトリップ特性

\begin{tabular}{|c|c|c|c|}
\hline & 平日 & 土曜 & 日曜 \\
\hline 総忡プ 数 & 5261 & 5055 & 4448 \\
\hline トップを行った人数 & 1653 & 1548 & 1454 \\
\hline 平均忡ップ 数（グロロ） & 2.9 & 2.8 & 2.5 \\
\hline 平均忡の゚ 数（祅） & 3.2 & 3.3 & 3.1 \\
\hline 1 以ッブの平均時間※1 & 35.4 & 33.0 & 33.1 \\
\hline 平均忡プチエーン数 & 2. 32 & 2.28 & 2.28 \\
\hline
\end{tabular}

続いて図-1 にトリップの時間帯別の割合を示す. 平日 では通勤時間帯にあたる 7 時〜 8 時台にピークが存在す るが，休日では午前中に明確なピークは存在しない，日 曜日は 17 時前後に緩やかなピークが存在する. 土曜日 は 17 時台に明確なピークを持つなど, トリップの時間 帯ごとの特性も異なることがうかがえる.

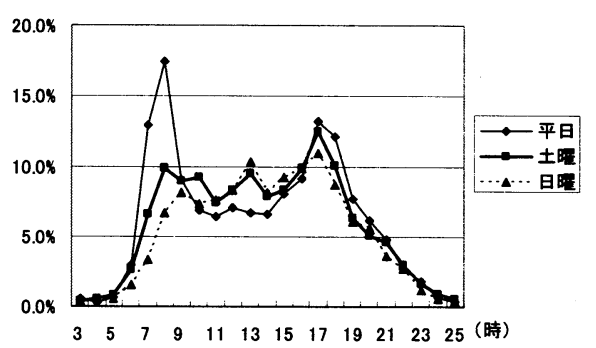

図 -1 時間带別のトリップ割合

続いて $\mathrm{AD}$ 調査の利点を生かして, 活動時間の配分実態 について分析を行う．活動時間配分について筆者らは, 京阪神 PT 調査のプレサーベイを用いて, 活動時間配分の モデル分析を行った ${ }^{3}$. そのときに構築した活動時間配 分を記述するモデルの結果から, 土曜と日曜では生活行 動時間配分は同じとは言えず，また，土・日を分離して それぞれモデル化するよりも，土曜・日曜の 48 時間を 一括してモデル化することが望ましいという結論を得て いる. ただし, 自宅内活動については 24 時間モデルと 48 時間モデルでは, 有意な差はなく, 外出活動が 48 時 間モデルのフィットを向上させ, パラメータの違いを生 み出しているということが明らかにされている。 つまり 土曜と日曜では買物や自由目的などの宅外活動時間にお いて，土曜に行ったものは日曜には行わないという代替 関係の存在が指摘されていた. そこで本研究ではこの結 論を参考に, PT 本体の付帯調査について活動時間配分な どの基礎的な指標についての確認を行う．その結果とし 
て図 - 2 に平日, 土曜, 日曜の自宅内活動, 移動, 自宅 外活動の平均活動時間配分を, 図-3に自宅外活動を取り 上げて，その内容を自由・拘束・必需・移動の大きく 4 分類して，それぞれの活動従事率を示した.

図 - 2 より平日は比較的自宅内活動時間が短く, 自宅 外活動時間が長くなっている. 休日（土曜，日曜）は自 宅内活動時間が長くなっている. また，同じ休日であっ ても土曜と日曜の間にも差が見られる. 土曜はいずれの 活動においても平日と日曜の中間の值をとっている. こ のことから，土曜と日曜では時間配分の構造が異なって いることが予想される.

また活動従事率をみると，自宅内活動は必需活動，拘 束活動, 自由活動とも全ての曜日で $90 \%$ を超えており差 はない. しかし図 - 3 に示すように自宅外活動をみると, 予想されるように必需・拘束活動が平日で高く, 自由活 動は休日の方が高い従事率になっている.これらの必 需・拘束活動をより詳細に分類すると，自宅外での仕事 の従事率が，平日で $48 \%$ ，土曜日で $28 \%$ ，日曜日では $16 \%$ と曜日ごとで大きな差があることが明らかになった.

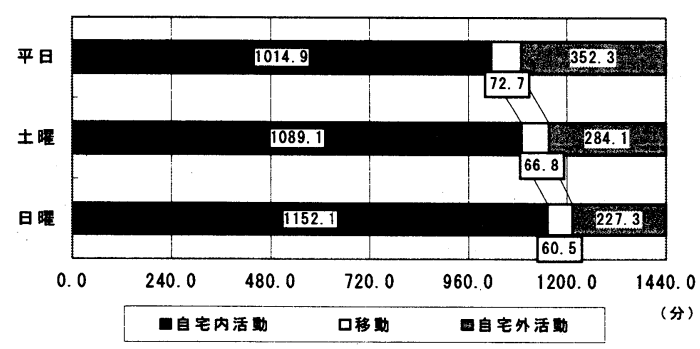

图 - 2 平均活動時間配分

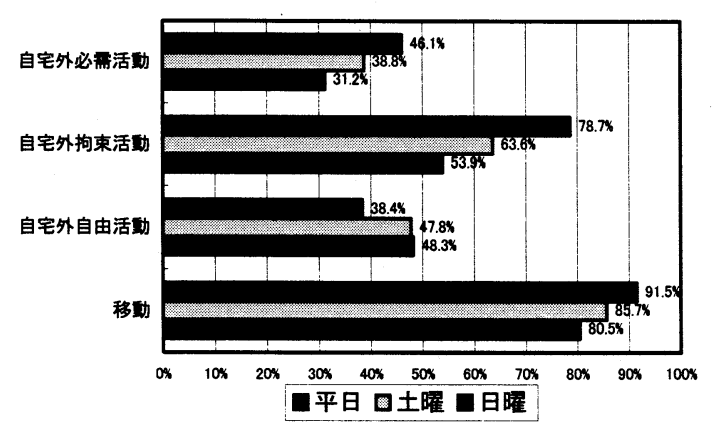

図 - 3 活動従事率（大分類）

\section{3．属性に着目した生活行動実態}

アクティビティ分析の示唆するところとして, 個人の 活動の決定には, 固定的な活動の存在が大きな役割を占 めていることが言われている. 2章では曜日に着目して 分類を行ってきたが，それはこの視点に立つと分析の視
点としてはあまり合理的でない，そこで，本章では個人 に着目し，当日勤務があるかないか，つまり当人にとっ て当日が休日であるのか勤務日であるのかという視点に 立って分析を行うこととする. ただし, 勤務以外にも長 時間の拘束を要求する活動であることの多い「会議など」, 「学習・お稽古」を行った人を含めて「勤務者」と定義 した. 勤務者の割合で曜日間の平均活動時間配分に差が 表れていると考え, 勤務者・非勤務者を分けてそれぞれ の生活行動を見ていくことにする.

各曜日の勤務者・非勤務者の割合は図 - 4 のようにな った. 平日は半数以上の人が仕事などに従事している. これまで同じ休日として定義してきた土曜日は日曜の倍 程度の人が仕事を行っている.

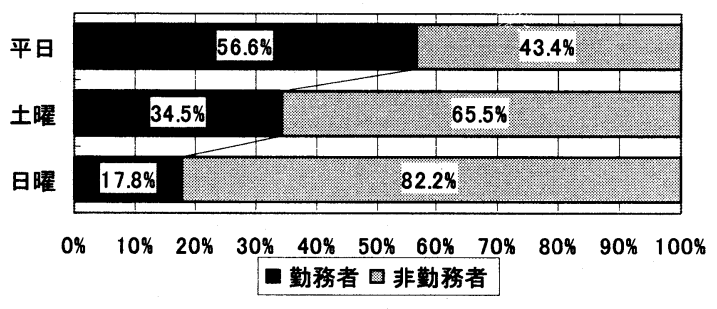

\section{図 - 4 勤務者・非勤務者の割合}

\section{（1）平均活動時間配分}

図 - 5 に各曜日別の勤務者の大分類での平均活動時間 配分を示す．この図は, 各曜日に勤務のあった全てのサ ンプルを集計したものである. このとき最も差があるの は必ず従事している仕事が含まれる自宅外拘束時間で, 平日より日曜の方が 67 分短くなっている. その他の活動 については 30 分以下の違いであり, 大きな差は見られな い.土曜と日曜では自宅内必需活動で 26 分の差が最大の 差であり，統計的にも有意な差はなかった.

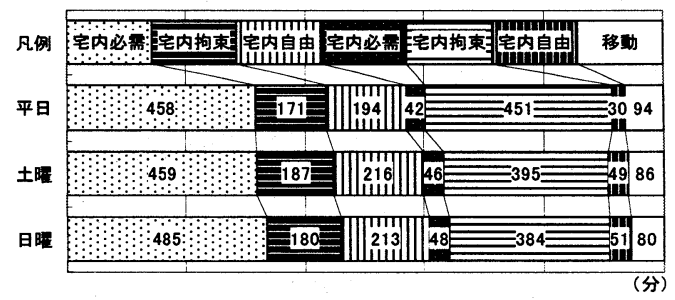

図 - 5 勤務者の平均活動時間配分

同じように図 - 6 に各曜日別の非勤務者の大分類での 平均活動時間配分を示す. 最も差があるのは自宅内拘束 時間で, 平日より日曜の方が 75 分短くなっている. その 他の活動には大きな差は見られない. 平日と日曜では時 間配分に差が見られるが，土曜と日曜では自宅内拘束時 間で 34 分の差が最大となり，ほとんど違いは見られない， このように当日勤務があるものと無いもの，つまり個人 
ごとに休日を定義することで，その活動時間配分はほと んど差がないものになる.

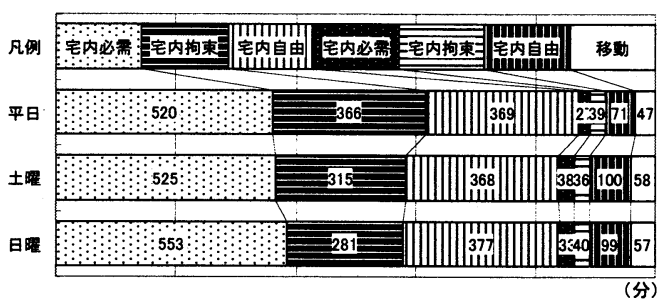

図 - 6 非勤務者の平均活動時間配分

\section{（2）年代別の生活行動特性}

勤務者・非勤務者の割合は性別および年代別に異なる と考えられるため, 年代別にどのような差異があるのか を簡単にまとめる．まず，年代別に分類して，各種活動 の従事率を求めた. その中から特に土曜と日曜で差が見 られたものとして, 図 - 7 に示すように 10 代の移動の従 事率があげられる.これを見ると修学率の高い 10 代では 平日 8 時台で $50 \%$ ある移動従事率が土曜日においても $30 \%$ あ. その一方日曜では 9 時台に $8 \%$ 程度あるだけ で午前中の移動従事率は非常に低い. 午後になると平日 は 17 時台，19 時台に移動のピークがあるが，土曜日は 午後 14 時から 19 時にかけて移動従事率が 10\%台を保っ ている. 2000 年の調查時点では学校の週休二日制が完全 に実施されておらず,その影響で 10 代においては土曜と 日曜が大きな差を見せている.これは学校の完全週休二 日が実施された現在では，異なった結果が得られる可能 性がある。

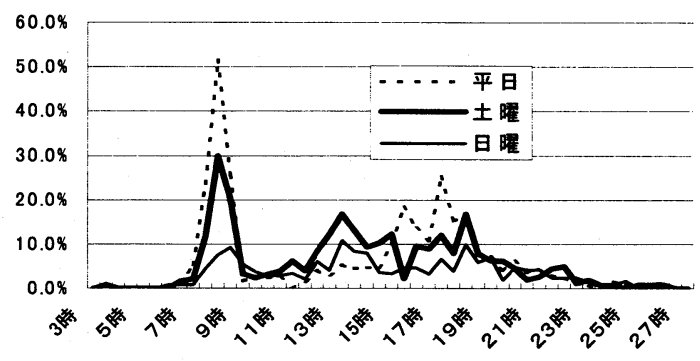

図 - 710 代の時間带別移動従事率

続いて, 土曜と日曜で差が見られた 30 代の買物活動従 事率を図 - 8 に示す. 買物活動のピークは土曜日では 15 時台にある, その後半分に落ち込むが，日曜日は 16 時か ら 17 時かけてしばらくの間ピークが続く.このピークの 連続性とピーク位置の差を考えると，土曜日と日曜日で は 30 代の買物活動が異なることが伺える．この違いは 10 代や 20 代では見られないものであった.

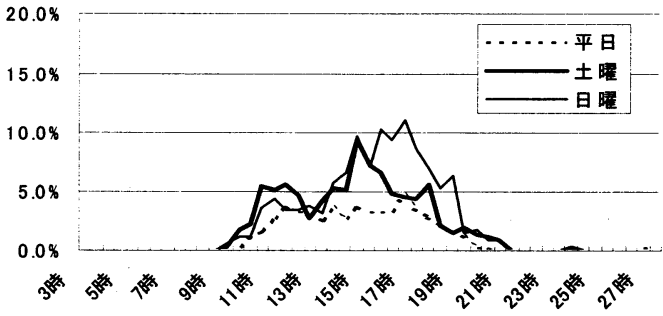

図 - 830 代の時間带別買物従事率

\section{4. 生活行動パターンのクラスター分析}

これまでは, 土・日の活動やトリップの実態を明確に するため集計的な指標を提示して分析を行ってきた. 集 計ベースでの指標は都市圈全体としての交通特性を知る ためには有効であるが，個人の行動パターンの違いは現 れてこない，そこで個人ベースの行動の要素である自宅 内の食事, 家事・身の回りの用事, 仕事・学習, 余暇活 動, 自宅外の食事, 拘束活動, 買物, 余㗇活動, 移動の 活動時間を変数として時間利用パターンの類型化を行っ た. 用いたサンプルは土曜, 日曜とも自宅外での仕事・ 学習がなく自営業ではない，つまり休日と考えられる 1072 人について,クラスター分析によって時間利用を類 型化した. クラスターの形成方法は, 対象となる個体数 が多いため非階層的手法である $\mathrm{K}$-means 法を用いた.

まず各クラスターの特徵を把握するため平均活動時間 を表 - 2 に示した. 全体の平均に比較して大きな值をつ けているものには下線を付し，小さな值となったものは 斜体で示した. この值から各クラスターの意味づけを行 うとクラスター 1 は「自宅内食事」「家事など」「「買い 物」の時間が長いため宅内拘束一買物型といえる．同様 に他のクラスターについても意味づけを行うとクラスタ -2 は買物型, クラスター 3 は自宅内拘束一余暇型, ク ラスター 4 は自宅内余暇型, クラスター 5 は自宅内仕 事・学習型, クラスター6は自宅外活動型と名付けられ る. 各クラスターの構成数は表 - 2 の一番下のようにな っている.クラスターごとにある程度特徵が明確になり, 基本的には買い物を除く自宅外活動に時間を多く費やし ているサンプルはひとつのクラスターを構成し，自宅内 活動での差異がクラスターの構成要因となっていること がわかる.

各クラスターの職業構成および年齢構成を，それぞれ 図 - 9, 図 - 10 に示した。.まず職業構成に着目すると全 体の平均から $40 \%$ が会社員, $20 \%$ が主婦， $30 \%$ が無職 である. それに対して，自宅内拘束一買物型（クラスタ ー1）では主婦が $50 \%$ 強となり，自宅内余㗇型（クラス ター4）は無職が $50 \%$ 弱を占めた. また自宅内仕事・学 習型（クラスター5）は会社員が $80 \%$ を占めている. 学 
生は自宅外活動型と自宅内仕事・学習型で全体と比較し て大きなシェアを占めている. 続いて年齢構成の特徵と しては, 職業の特徵と関連して, 自宅内余㗇型では 70 歳以上の高齢者層が高い 割合を占め, 逆に自宅外活動型 では低い割合を占めた．自宅外活動型では 20 代のシェ アが高くなり学生が高い割合を占めたことを反映してい ると考えられる. このように基本的には固定的活動が小 さく自由配分活動時間が多い日だけを取り出してきたが, ある程度その使い方には個人属性が関係していることが わかる。

次に, 各クラスターでの土・日の割合を図 - 11 に示し た.このクラスター分析は土・日それぞれ 1 日を単位と してクラスターにかけているため，連続した 2 日という 単位での分析とはなっていない，そこでそれぞれの土・ 日に分けた場合のクラスターの存在割合と個人のクラス ター帰属から 2 日間の変動を確認する. 集計值では土曜 と日曜で同一クラスターに帰属する割合が高く，日曜日 に買物型が $3.6 \%$ 増加しそれ以外がわずか減少する程度 の変化である. 個人のクラスターへの帰属に着目すると 土・日とも帰属するクラスターが変わらない人は 593 人

(55.3\%) となり, 残りの $44.7 \%$ はクラスターが変化し ている.

クラスター変化は, 買い物型(クラスター2)が支配する 中での変動となっているが，買い物と関連が強いクラス ター（クラスター1，3，6）とそれほど高くないクラス ター $(4 ， 5)$ などの違いが見られる. しかしこれらの 生活パターンの変化がトータルでキャンセルしたことに

表 - 2 クラスター別平均活動時間（グロス）

\begin{tabular}{|c|c|c|c|c|c|c|c|}
\hline & 1 & 2 & 3 & 4 & 5 & 6 & 全体 \\
\hline 食事(内 & $\underline{161.0}$ & 123.8 & $\underline{176.1}$ & 131.1 & 129.8 & 55.5 & 125.4 \\
\hline 家事など & 882.2 & 280.8 & $\underline{\underline{607.7}}$ & 104.7 & 109.1 & 121.1 & 314.4 \\
\hline 仕事·学 & 11.9 & 11.9 & 11.5 & 23.8 & $\underline{\underline{525.8}}$ & 12.9 & 40.2 \\
\hline 余腵(内 & 255.4 & 340.8 & $\underline{\underline{762.9}}$ & 804.6 & 235.1 & 153.5 & 438.0 \\
\hline 拘束活動 & 7.1 & 18.0 & 6.8 & 6.0 & 4.0 & $\underline{48.9}$ & 16.7 \\
\hline 食事(外 & 17.2 & 20.6 & 16.1 & 72 & 6.2 & 82.9 & 24.9 \\
\hline 買物 & $\underline{\underline{57.6}}$ & $\underline{65.6}$ & 44.1 & 28.9 & 13.5 & 35.3 & 47.9 \\
\hline 余㗇(外 & 37.4 & 48.4 & 39.7 & 45.2 & 24.0 & 390.2 & 92.2 \\
\hline 移動 & 43.4 & 64.1 & 28.4 & 27.1 & 20.0 & $\underline{163.0}$ & 62.0 \\
\hline トリップ数 & 2.4 & 2.8 & 2.2 & 1.8 & 1.4 & 3.1 & 2.5 \\
\hline 総けップ時間 & 45.5 & 67.5 & 29.8 & 28.3 & 27.1 & 164.3 & 64.5 \\
\hline 鉄道 & 5.9 & 14.4 & 6.2 & 4.9 & 3.4 & $\underline{\underline{59.2}}$ & 16.3 \\
\hline バス & 1.9 & 3.5 & 0.7 & 1.2 & 0.0 & $\underline{\underline{10.4}}$ & 3.3 \\
\hline 自動車 & 25.2 & 37.1 & 14.5 & 14.0 & 18.7 & $\underline{\underline{74.3}}$ & 32.9 \\
\hline 二輪 & 29 & 5.0 & 3.7 & 3.6 & 3.3 & $\underline{\underline{7.5}}$ & 4.6 \\
\hline 徒歩 & $\underline{\underline{7.0}}$ & $\underline{\underline{7.5}}$ & 4.7 & 4.6 & 1.7 & 4.4 & 5.8 \\
\hline 構成数 & 256 & 821 & 200 & 460 & 107 & 300 & 2144 \\
\hline
\end{tabular}

よって，集計的な時間配分が一致したと考えられる.

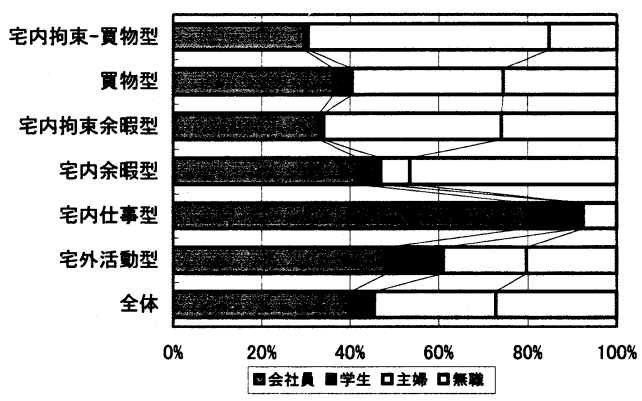

図 -9 各クラスターの職業の構成割合

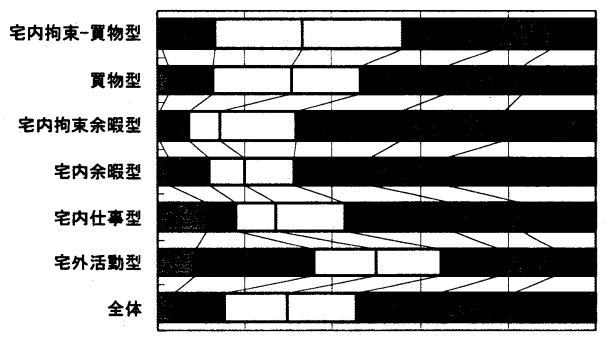

$\begin{array}{llllll}0 \% & 20 \% & 40 \% & 60 \% & 80 \% & 100 \%\end{array}$

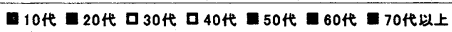

図 -10 各クラスターの年齢構成割合

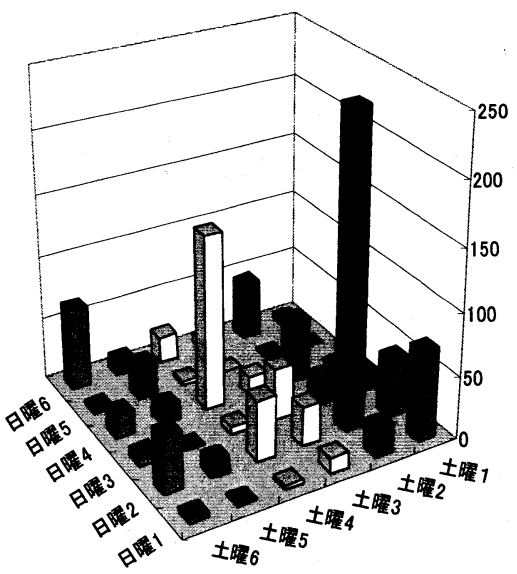

図 - 11 土・日間のクラスターの帰属 


\section{5. おわりに}

本研究では, $\mathrm{AD}$ 調査を用いて, 休日, 特に土曜と日曜 日の違いを中心に特性を明らかにした. その結果，土・ 日をそれぞれ休日として定義して全体を集計的に見た場 合には，土曜と日曜は異なる性質を持つことが明らかに なった. しかし分析の視点を個人的な休日（その日に自 宅外の固定活動がない）別にしたところ, 活動時間配分 などではほとんど差がなくなった．交通計画の立場から は，個人ごとの休日を前提とした交通計画を策定するこ とは困難であるため, 曜日に着目せざるを得ないが，休 日の曜日間変動の多くはその日の勤務者の割合に依存す ることが明らかになった。つまり休日の調査を実施する ときに，土曜と日曜の差は，勤務者の割合があらかじめ わかっている場合，もしくは勤務者の割合を補完的に調 査できるという前提に立つならば，集計的な時間利用や トリップ特性を知る上で 2 日間の連続調査の必要性はそ れほど無いといえる.

また，4章で行ったクラスター分析から個人ベースで の行動特性を検証した結果からは，生活パターンは個人 の影響をうけ，そのうち土・日に活動パターンを変更す る割合は半数となり, 変化は買い物型が支配する中で, クラスターごとの特徴が見られた。

以上の結果から, 休日交通の調査は, 集計的指標化に おいては，個人的な休日に着目することにより独立な一 日とすることが可能であるが，個人的な活動パターンの 変動に着目するときには, 約半数が活動パターンを変化 させることから，土・日の両日調査が必要となってくる といえる.
注

1.もちろん現在のITS の発展を考えたときには将来的には個 人ベースの課題対応型の交通計画というものも成立する と考えられる.

参考文献

1）西井和夫:都市圈休日交通一の対応，都市計画,No.225,2000

2) 西井和夫,森川高行,兵藤哲朗,岡本直久,鈴木紀一,毛利雄一,古屋秀 樹,佐々木邦明,西野至,河辺隆英:休日·観光交通一の対応: 調查·分 析手法の課題整理と展望, 土木計画学研究・講演 集,No.22(1),pp.671-678.1999.

3）屋井鉄雄: 休日交通を取り巻く最近の变化と分析技法の展開, 交通工 学, Vol.25, pp.58-66, 1993.

4) 土木計画学研究委員会: 地域間交流活性化火観光一分析・計画手法 と政策課題一,第 34 回土木計画学シンポジウム資料,1998.

5）吉田朗，原田昇：休日の買回り品買い物交通を対象とした買い物 頻度選択モデルの研究, 土木学会論文集, NO.413/IV12, pp.107-116, 1990.

6) 室町泰徳, 原田昇, 吉田明 : 駐車需要の時間変動を考虑した駐車 場選択モデルに関する研究，都市計画論文集，No.10, pp.47-54, 1992.

7）厚生労働省 : 平成 15 年就労条件総合調查の概況, 2003.

8）国土交通省道路局: 平成 11 年度 道路交通センサス, 交通工学 研究会, 2001.

9）西井和夫，佐々木邦明，西野至，今尾友絵 : 都市圈休日生活行動 における活動時間配分特性, 土木計画学研究・論文集, Vol. 19, №. 3, pp. 561-568, 2002.

10）杉恵頼寧, 芦沢哲蔵, 羽藤英二: 個人の 1 週間の交通行動の特性, 土木計画学研究・講演集, No.13, pp.549 pp.554, 1990

11）杉恵頼寧, 芦沢哲蔵 : 買物・私用交通の曜日変動特性, 第 26 回日 本都市計画学会学術研究論文集, pp.277-282, 1991

12）吉田信博, 朝山勝人, 長谷川哲郎 : 京阪神都市圈におけるアクテ イビティ・ダイアリー調查データの収集・分析, 土木計画学研究・ 講演集, No. 23, CD-ROM, 2000.

\section{休日の活動－交通の実態分析と休日調査へのインプリケーション}

佐々木邦明, 林篤史, 西井和夫

休日の総合的な交通計画の必要性が高まる中で，休日の交通計画の基礎資料として，休日の交通調査につ いては明確な指針はまだない，そこで，本研究では休日の交通分析に関する情報抽出を目的とした．具体的 には京阪神PT付帯の土・日と連続してとられた生活行動調査に基づいて，それぞれの特性を集計的な指標か ら明らかにした. また, 個人特性に基づいた集計化とクラスター分析の結果より, 調査目的に応じた分析単 位を設定の必要性を示した.

\section{An Analysis of Weekend Activity-Travel and Implications for Surveys on Weekend Activity}

by Kuniaki SASAKI, Atsushi HAYASHI, Kazuo NISHII The necessity of weekend transportation plan is getting more and more important. However, even the activity-travel unit as basic information of transportation planning is not evident. Thus this research focused on the basic analysis of weekend activity-travel behavior. Both the aggregate analysis and the cluster analysis were adopted for its purpose. The aggregate results showed that the activity and travel varies between the Saturday and Sunday. However, the segmentation of non-workers and workers cleared the difference within each segment. Therefore, we concluded that the survey unit should be dependent on the analyzing purpose. 